\title{
EVALUASI PENGELOLAAN DANA DESA DI DESA KALASEY DUA KECAMATAN MANDOLANG KABUPATEN MINAHASA
}

\author{
Tita Natalia Kaluntas \\ Olly Esry Harryani Laoh \\ Yolanda Pinky Ivanna Rori
}

\begin{tabular}{ll}
\hline Naskah diterima melalui Website Jurnal Ilmiah Agrisosioekonomi Fakultas Pertanian UNSRAT & : Sabtu, 23 Maret 2019 \\
Disetujui diterbitkan & : Selasa, 22 April 2019 \\
\hline
\end{tabular}

\begin{abstract}
This study aims to evaluate Village Fund management in Kalasey Dua Village, Mandolang Sub-district, Minahasa Regency. The study was conducted from May 2018 to January 2019. The data used in this study were primary data and secondary data. Primary data was collected based on interviews with two members of the Village Consultation Board (BPD), three village officials, and 50 community members to find out their responses to Village Fund management. The fifty community members were selected community members that have over the age of 21 years and had lived in the research village for more than 10 years. So the total respondents were 55 people. Interviews with community members were used by Likert Scale. Secondary data in this study came from the archives and reports of Kalasey Dua Village office in the form of Village Monographs, Village Fund Management Data and other documents relating to the management of the Kalasey Dua Village Village Fund; and through books available at local bookstores; and the internet. Internet used google searching to access articles from various scientific journals and theses from other universities related to the topic of this research. Data analysis using descriptive analysis. The results of the study indicate that overall the Village Funds received in Kalasey Dua Village have been managed properly by the government or the management, both in the management procedure with the availability of documents; and adhere to the principles of village fund management that consists of justice, needs, village authority, participation, self-management and village-based resources, village typology, transparency and accountability; and the community have felt the benefits. The Village Fund has been giving benefit to community of the village, both in the construction of infrastructure (roads, culverts, solar street lighting) and the empowerment of rural communities (by technical guidance of the management of Village-Owned Enterprises or BUMDES outside the region). ${ }^{* \text { gmhk+erprm* }}$
\end{abstract}

Keywords: Evaluation, Management, Procedures and Principles, Village Funds, Likert Scale

\begin{abstract}
ABSTRAK
Penelitian ini bertujuan untuk mengevaluasi pengelolaan Dana Desa yang ada di Desa Kalasey Dua Kecamatan Mandolang Kabupaten Minahasa. Penelitian dilaksanakan dari bulan Mei 2018 sampai bulan Januari 2019. Data yang digunakan dalam penelitian ini yaitu data primer dan data sekunder. Data primer yang dikumpulkan berdasarkan wawancara dengan dua anggota Badan Permusyaratan Desa (BPD), tiga perangkat desa, dan 50 anggota masyarakat untuk mengetahui tanggapan mereka terhadap pengelolaan Dana Desa. Kelima puluh anggota masyarakat yang dipilih secara sengaja anggota masyarakat yang berusia diatas 21 tahun dan telah tinggal di desa penelitian lebih dari 10 tahun. Jadi total responden sebanyak 55 orang Khusus wawancara pada anggota masyarakat digunakan alat ukur Skala Likert. Data sekunder dalam penelitian ini berasal dari arsip-arsip maupun laporan kegiatan yang dimiliki oleh Desa Kalasey Dua berupa Monografi Desa, Data Pengelolaan Dana Desa dan dokumen lain yang berkaitan dengan pengelolaan Dana Desa Desa Kalasey Dua; serta melalui buku-buku yang tersedia di toko buku local; dan internet dengan menggunakan google searching untuk mengakses artikel dari berbagai jurnal ilmiah dan skripsi dari perguruan tinggi lain yang berkaitan dengan topik penelitian ini. Analisis data menggunakan analisis deskriptif. Hasil penelitian menunjukkan bahwa secara keseluruhan Dana Desa yang diterima di Desa Kalasey Dua telah dikelola secara baik oleh pemerintah atau pihak pengelola, baik secara prosedur pengelolaan dengan adanya kelengkapan dokumen; serta menaati prinsip pengelolaan dana desa meliputi keadilan, kebutuhan, kewenangan desa, partisipatif, swakelola dan berbasis sumberdaya desa, tipologi desa, transparan dan akuntabel; dan masyarakat sudah dapat merasakan manfaatnya. Dana Desa telah bermanfaat bagi pembangunan di desa, baik pembangunan infrastruktur (yaitu: jalan, gorong-gorong, penerangan jalan tenaga surya) maupun pemberdayaan masyarakat desa (bimbingan teknis pengurus Badan Usaha Milik Desa atau BUMDES ke luar daerah). ${ }^{\text {" }}{ }^{\text {gmhkterprm* }}$
\end{abstract}

Kata kunci : Evaluasi, Pengelolaan, Prosedur dan Prinsip, Dana Desa, Skala Likert 


\section{PENDAHULUAN}

\section{Latar Belakang}

Indonesia saat ini terus mengupayakan peningkatan pembangunan nasional agar laju pembangunan daerah serta pembangunan desa dan kota semakin seimbang dan serasi kebijakan otonomi daerah memberikan wewenang kepada daerah untuk mengatur dan mengurus kebutuhan masyarakat daerahnya dimana konsep pembangunan harus lebih diarahkan lagi pada pembangunan berbasis tingkatan terendah dalam suatu struktur pemerintahan yaitu desa.

Desa sebagai sebuah kawasan yang otonomi memang diberikan hak-hak istimewa, diantaranya adalah terkait pengelolaan keuangan dan alokasi dana desa, pemilihan kepala desa serta proses pembangunan. Desa diberikan kewenangan dan sumber dana yang memadai agar dapat mengelola potensi yang dimilikinya guna meningkatkan ekonomi dan kesejahteraan masyarakat.

Dalam buku saku Dana Desa yang diterbitkan oleh Kementerian Keuangan menjelaskan bahwa setiap tahun Pemerintah Pusat telah mengganggarkan Dana Desa yang cukup besar untuk diberikan kepada Desa. Untuk total jumlah besaran anggaran dana desa tiga tahun pertama dapat dilihat di Tabel 1 .

Tabel 1. Besaran Dana Desa di Indonesia tahun 2015-2017

\begin{tabular}{clcc}
\hline & \multicolumn{3}{c}{ Tahun } \\
\cline { 2 - 4 } & \multicolumn{1}{c}{2015} & \multicolumn{1}{c}{2016} & 2017 \\
\hline Total Anggaran & Rp. 20.7 & Rp. 46.98 Triliun & Rp. 60 \\
& Triliun & & Triliun \\
Rata-rata per Desa & Rp. 280 Juta & Rp. 628 Juta & Rp. 800 Juta \\
\hline Sumber · Buku Saku Dana Desa yang diterbitkan oleh Kementerian Keuangan
\end{tabular}

Tabel 1 menunjukkan bahwa jumlah dana yang diterima desa cukup besar dan terus meningkat setiap tahunnya. Agar tidak terjadi penyimpangan dalam pengelolaan dana yang ada di desa harus diikuti dengan pengawasan yang kuat. Badan Permusyawaratan Desa yang merupakan lembaga yang mempunyai fungsi pengawasan diharapkan bisa menjalankan perannya secara sungguh-sungguh terutama dalam hal penggunaan anggaran. . Undangundang dan Peraturan Pemerintah sudah memberikan payung hukum yang jelas sehingga BPD tidak perlu ragu dalam menjalankan fungsinya untuk melakukan pengawasan terhadap kinerja kepala desa. Juga diperlukan partisipasi masyarakat dalam mengawasi pengelolaan dana desa, karena masyarakat mempunyai hak untuk meminta dan mendapatkan informasi terhadap pengelolaan dana desa, sesuai yang telah termaktub dalam Pasal 68 Undang-Undang Nomor 6 Tahun 2014 tentang Desa, agar apa yang menjadi tujuan dari dana desa bisa terealisasi dengan baik.
Mengingat dana yang diterima oleh desa jumlahnya cukup besar dan terus meningkat setiap tahunnya, maka dalam menyelenggarakan pemerintahan dan pengelolaan keuangan desa, dibutuhkan kapasitas aparatur desa yang handal dan sarana lainnya yang memadai agar pelaksanaannya menjadi lebih terarah dan akuntabel. Peran pemerintah desa dalam pembangunan desa pada era otonomi daerah sangat penting, dimana secara langsung mendukung pemerintah daerah dalam membangun pondasi daerahnya sendiri.

Dalam buku Indeks Pembangunan Desa 2014 di sebutkan ada 74.093 desa penerima anggaran Dana Desa yang terbagi di 34 provinsi yang ada di Indonesia. Salah satunya Desa Kalasey Dua yang berada di Kecamatan Mandolang Kabupaten Minahasa Provinsi Sulawesi utara. Pada tahun 2017 desa Kalasey Dua menerima Dana Desa sebesar Rp. 772.117.000. Sebelum adanya anggaran Desa Desa yang diberikan oleh pemerintah pusat, pemerintah desa sudah mengupayakan pembangunan desa dari sumber-sumber pendapatan yang diterima oleh desa. Anggaran Dana Desa yang dibilang cukup besar, jika dapat mampu dikelola dengan baik oleh pemerintah desa maka dapat mendorong pembangunan desa yang lebih signifikan. Pada Tahun 2017 juga terjadi permasalahan dalam pengelolaan dana desa yaitu adanya laporan masyarakat terhadap kepala desa mengenai penyalahgunaan dana desa akan tetapi hasil keputusan pengadilan menyatakan tidak terbukti bersalah.

Berdasarkan uraian diatas muncul masalah yang menarik untuk diteliti berkaitan dengan pengelolaan Dana Desa yang ada di Desa Kalasey Dua. Sehinggapenulis merasa penting untuk melakukan penelitian dan penulis mengangkat judul tentang penelitian ini yaitu "Evaluasi Pengelolaan Dana Desa di Desa Kalasey Dua Kecamatan Mandolang Kabupaten Minahasa”.

\section{Evaluasi}

Evaluasi adalah suatu cara untuk menilai apakah suatu kebijakan atau program itu berjalan dengan baik atau tidak (Zaki 2017). Menurut Siagian dalam Alumudin (2018) mendefinisikan evaluasi adalah sebagai proses pengukuran dan pembandingan dari hasil-hasil pekerjaan yang nyatanya dicapai dengan hasil-hasil yang seharusnya dicapai. Sedangkan menurut Wirawan dalam Alumudin (2018) evaluasi adalah proses pengumpulan dan menyajikan informasi mengenai objek evaluasi, menilainya dengan standar evaluasi dan evaluasinya dipergunakan untuk mengambil keputusan mengenai objek evaluasi. 


\section{Dana Desa (DD)}

Dalam Peraturan Pemerintah No. 60 Tahun 2014 pasal 1 Dana Desa adalah dana yang bersumber dari Anggaran Pendapatan dan Belanja Negara yang diperuntukkan bagi Desa yang ditransfer melalui Anggaran Pendapatan dan Belanja Daerah kabupaten/kota dan lingkungan untuk membiayai penyelenggaraan pemerintah, pelaksanaan pembangunan, pimbinaan masyarakat, dan pemberdayaan masyarakat.

Dalam Peraturan Pemerintah Republik Indonesia No. 22 Tahun 2015 tentang perubahan atas Peraturan Pemerintah No. 60 Tahun 2014 tentang Dana Desa yang bersumber dari Anggaran Pendapatan dan Belanja Negara dijelaskan devinisi dana desa adalah dana yang bersumber dari Anggaran dan Belanja Negara yang diperuntukkan bagi desa yang ditransfer melalui Anggaran Pendapatan dan Belanja Daerah, kabupaten/kota dan digunakan untuk membiayai penyelenggaraan pemerintahan, pelaksanaan pembangunan, pembinaan masyarakat dan pemberdayaan masyarakat.

Pengelolaan Dana Desa harus berpedoman pada prinsip penggunaan Dana Desa yaitu sebagai berikut :

1. Keadilan : Mengutamakan hak dan kepentingan seluruh warga desa tanpa membeda-bedakan.

2. Kebutuhan : Mendahulukan kepentingan Desa yang lebih mendesak, lebih dibutuhkan dan berhubungan langsung dengan kepentingan sebagian besar masyarakat desa.

3. Kewenangan Desa : Mengutamakan kewenangan hak asal usul dan kewenangan lokal berskala desa.

4. Partisipatif : Mengutamakan prakarsa dan kreatifitas masyarakat.

5. Swakelola Dan Berbasis Sumber Daya Desa : Mengutamakan pelaksanaan secara mandiri dengan pendayagunaan sumberdaya alam desa, mengutamakan tenaga, pikaran dan keterampilan warga desa dan kearifan lokal.

6. Tipologi Desa : Mempertimbangkan keadaan dan kenyataan karakteristik geografis, sosiologi, antropogi, ekonomi, dan ekologi desa yang khas, serta perubahan atau perkembangan dan kemajuan desa.

Dalam Peraturan Menteri Desa, Pembangunan Daerah Tertinggal, dan Transmigrasi No. 5 Tahun 2015 Prioritas penggunaan Dana Desa untuk pembangunan Desa dialokasikan untuk mencapai tujuan pembangunan Desa yaitu meningkatkan kesejahteraan masyarakat Desa dan kualitas hidup manusia serta penanggulangan kemiskinan, melalui: Pemenuhan kebutuhan dasar, Pembangunan sarana dan prasarana Desa, Pengembangan potensi ekonomi lokal; dan, Pemanfaatan sumber daya alam dan lingkungan secara berkelanjutan.

\section{Rumusan Masalah Penelitian}

Bagaimana pengelolaan dana desa di Desa Kalasey Dua Kecamatan Mandolang Kabupaten Minahasa

\section{Tujuan Penelitian}

Penelitian ini dilakukan dengan tujuan untuk mengevaluasi pengelolaan Dana Desa yang ada di Desa Kalasey Dua Kecamatan Mandolang Kabupaten Minahasa.

\section{Manfaat Penelitian}

Manfaat dari penelitian ini diharapkan dapat meningkatkan pemahaman dan pegetahuan mengenai pengelolaan Dana Desa bagi semua pihak yang terkait.

\section{METODE PENELITIAN}

\section{Lokasi dan Waktu Penelitian}

Penelitian dilaksanakan di Desa Kalasey Dua, Kecamatan Mandolang, Kabupaten Minahasa, Provinsi Sulawesi Utara. Penelitian dilakukan dari bulan Mei 2018 sampai bulan Januari 2019.

\section{Metode Pengumpulan Data}

Data yang digunakan dalam penelitian ini yaitu data primer dan data sekunder. Data primer merupakan data yang diperoleh secara langsung dari objek penelitian, baik melalui wawancara dengan narasumber, dan pengumpulan data lapangan lainnya. Data primer yang dibutuhkan adalah tanggapan Badan Permusyawaratan Desa, perangkat desa serta tanggapan masyarakat tentang pengelolaan Dana Desa. Dalam penelitian ini, data diperoleh dengan cara wawancara dengan responden dalam hal ini pemerintah desa dan menyebarkan kuesioner yang telah disediakan oleh peneliti untuk masyarakat desa. Metode yang digunakan adalah dengan kuesioner tertutup menggunakan skala likert. Jawaban setiap item instrument yang menggunakan skala likert mempunyai gradasi dari sangat positif sampai sangat negatif (Sugiyono dalam Rosipah 2014).

Sedangkan data sekunder merupakan data yang diperoleh secara tidak langsung dari objek yang diteliti yang antara lain dilakukan melalui studi literatur, kepustakaan dan arsip/laporan. Data sekunder dalam penelitian ini berasal dari dokumen, arsip-arsip maupun laporan kegiatan yang dimiliki oleh Desa Kalasey Dua, seperti monografi desa, data pengelolaan Dana Desa dan dokumen lain yang berkaitan dengan pengelolaan Dana Desa desa Kalasey Dua. 


\section{Populasi dan Sampel}

Populasi dalam penelitian ini, adalah masyarakat desa Kalasey Dua yang memenuhi kriteria yang telah ditetapkan. Sampel adalah sebagian dari populasi yang karakteristiknya hendak diteliti dan dianggap bisa mewakili keseluruhan populasi. Pengambilan sampel ditentukan dengan metode purposive sampling dengan tujuan untuk mendapatkan informasi dari individu maupun kelompok dengan sasaran yang tepat. Pengambilan sampel dalam hal ini terbatas pada jenis orang tertentu yang dapat memberikan informasi yang diinginkan untuk jumlah sampel yang diambil berjumlah 55 responden.

Adapun informan penelitian yang akan diwawancarai yaitu :

1. Sekretaris Desa (1 Responden)

2. Badan Permusyawaratan Desa (BPD) (2 responden)

3. Perangkat Desa (2 responden)

4. Masyarakat (50 responden)

\section{Konsep Pengukuran Variabel}

Variabel-variabel yang diukur dalam penelitian ini adalah proses pengelolaan Dana Desa dalam hal ini mengenai prosedur yang merupakan dokumen-dokumen terkait pengelolaan dana desa dan prinsip pengelolaan dana desa. Variabel-variabel tersebut meliputi :

\section{RKP-Desa}

Untuk bisa mencairkan dana desa maka pemerintah desa harus lebih dahulu menyusun Rencana Kerja Pemerintah Desa (RKP-Desa). RKP-Desa merupakan penjabaran dari Rencana Pembangunan Jangka Menengah Desa untuk jangka waktu 1 tahun anggaran.

2.Anggaran Pendapatan dan Belanja Desa (APBDes)

APBDesa adalah peraturan desa yang memuat sumber-sumber penerimaan dan alokasi pengeluaran desa dalam kurun waktu satu tahun. APBDes disusun berdasar pada RKPDesa. APBDes menjamin kepastian rencana kegiatan, dalam arti mengikat pemerintah desa dan semua pihak yang terkait, untuk melaksanakan kegiatan sesuai rencana yang telah ditetapkan, serta menjamin tersedianya dalam jumlah yang tertentu untuk melaksanakan kegiatan. APBDesa menjamin kelayakan sebuah kegiatan dari segi pendanaan, sehingga dapat dipastikan kelayakan hasil kegiatan secara teknis.

3.Rencana Penggunaan Dana (RPD) Dana Desa

RPD Dana Desa merupakan dokumen pelaksanaan anggaran kegiatan desa, khususnya dana desa yang dibuat oleh pelaksana kegiatan.

\section{Laporan Realisasi Anggaran Desa}

Untuk mempertanggungjawabkan keuangan desa dan merealisasikan anggaran desa yang sudah dibuat, maka perlu dibuat Laporan Realisasi Anggaran (LRA) berdasarkan SPAP yang menyajikan informasi realisasi pendapatan, belanja, transfer, surplus/deficit dan pembiayaan, yang masing-masing diperbandingkan dengan anggarannya dalam satu periode. Dalam penelitian ini Laporan Realisasi Anggaran Desa dijadikan suatu acuan dalam mengevaluasi pengelolaan Dana Desa, untuk melihat apakah pelaksaan telah sesuai dengan perencanaan yang telah dibuat dan apakah setiap rencana dapat terlaksanakan dengan baik atau tidak.

5. Dana Desa

Dana desa merupakan sumber pendapatan desa terbesar dengan jumlah nominal yang cukup banyak. Dalam penelitian akan meneliti bagaimana penilaian atau pendapat informan mengenai pengelolaan dana desa ini apakah sesuai dengan prinsip pengelolaan, juga akan meneliti dampak/manfaat yang didapat setelah adanya penerimaan dana desa. Adapun prinsipprinsip pengelolaan yang dimaksud yaitu Keadilan, Kebutuhan, Kewenangan Desa, Partisipasi, Swakelola Dan Berbasis Sumberdaya Masyarakat, Tipologi Desa, Transparan/Terbuka dan Akuntabel.

\section{Metode Analisis Data}

Analisis data dalam penelitian ini dilakukan secara deskriptif kualitatif untuk menganalisis data dengan cara memaparkan, mengelola, menggambarkan dan menafsirkan hasil penelitian dengan kata-kata dan kalimat sebagai jawaban atas permasalahan yang diteliti, serta mengorganisasi dan menganalisis data angka agar memberikan gambaran secara teratur, ringkas, dan jelas mengenai suatu gejala, peristiwa atau keadaan, sehinga dapat ditarik pengertian atau makna tertentu (Sudijono 2015). Dalam penelitian ini bertujuan untuk mengevaluasi pengelolaan dana desa di Desa Kalasey Dua, serta meminta tanggapan sekretaris desa, Badan Permusyawaran Desa, Perangkat Desa, serta masyarakat desa tentang pengelolaan dana desa yang telah dilaksanakan pemerintah desa. Metode analisis data untuk tanggapan masyarakat desa menggunakan analisis data dengan empat kriteria skor pernyataan positif :

$\begin{array}{lc}\quad \text { Pernyataan } & \text { Skor } \\ \text { Sangat Setuju } & 4 \\ \text { Setuju } & 3 \\ \text { Kurang Setuju } & 2 \\ \text { Tidak Setuju } & 1\end{array}$

Untuk mencari besarnya persentase menggunakan rumus persentase :

$$
P=\frac{F}{N} \times 100 \%
$$

Keterangan :

$\mathrm{P}=$ Persentase

$\mathrm{F}=$ Frekuensi

$\mathrm{N}=$ Jumlah Sampel 


\section{HASIL DAN PEMBAHASAN}

\section{Deskripsi Daerah Penelitian}

Desa Kalasey Dua merupakan bagian integral dari Kecamatan Mandolang Kabupaten Minahasa Provinsi Sulawesi Utara. Desa kalasey Dua berdiri pada tanggal 27 Januari 1995 yang adalah hasil pemekaran dari Desa Kalasey menjadi 2 (Dua) Desa, dari segi geografis berkedudukan dipinggiran Kota Manado (berbatasan dengan Kota Manado) yang asal usul penduduk Pribuminya adalah masyarakat bekas buruh perkebunan asiatik Kalasey dan sebagian masyarakat pindahan dari Kelurahan Malalayang Dua, pesisir pantai Kalasey (Togas) yang dimukimkan oleh Pemerintah Provinsi Sulawesi Utara melalui program resetlementer 1983. Desa Kalasey Dua diresmikan menjadi desa difinitif pada tanggal 29 September 1996.

\section{Dana Desa di Desa Kalasey Dua}

Dalam dua tahun peluncuran Dana Desa, desa Kalasey Dua telah berhasil melaksanakan pembangunan antara lain, pembuatan Drainase dengan panjang $250 \mathrm{M}$, Rabat beton sepanjang $450 \mathrm{M}$ dan Perkerasan jalan lapis sirtu sepanjang $110 \mathrm{M}$ pada tahun 2015. Dan pembangunan Rabat beton sepanjang $450 \mathrm{M}$, Perkerasan jalan lapis sirtu, gorong-gorong 4 unit, tugu batasdesa 1 unit, serta Lampu penerangan jalan tenaga surya 2 unit pada tahun 2016. Adapun Rencana Kerja Pemerintah Desa tahun 2017 dapat dilihat pada Tabel 5.

\begin{tabular}{lr}
\multicolumn{2}{c}{ Tabel 5. Rencana Kerja Pemerintah Desa, Desa Kalasey Dua Tahun 2017} \\
\hline \multicolumn{2}{c}{ Uumlah (Rp) } \\
\hline Bidang penyelenggaraan Pemerintah Desa & \\
\hline Penghasilan Tetap dan Tunjangan & 198.360 .000 \\
Tunjangan BPD & 15.000 .000 \\
Operasional Perkantoran & 30.000 .000 \\
\hline Bidang Pembangunan & 300.000 .000 \\
\hline Pengaspalan Jalan Lapen & 150.000 .000 \\
Rabat Beton & 100.000 .000 \\
Perintisan Jalan Lorong & 150.000 .000 \\
Talud & 50.000 .000 \\
Gorong-gorong & 150.000 .000 \\
Perkerasan Jalan & 200.000 .000 \\
Tanggul Sungai & 100.000 .000 \\
Bak Penampung Air Bersih & 125.000 .000 \\
Lampu Jalan Tenaga Surya & \\
\hline Bidang Pembinaan Masyarakat & 5.000 .000 \\
\hline Pelatihan Keterampilan & 5.000 .000 \\
Pelatihan Karang Taruna & \\
Bidang Pemberdayaan Masyarakat & 40.000 .000 \\
Pengembangan Usaha kelompok Nelayan & 50.000 .000 \\
Pengadaan Bibit Cengkih & 10.000 .000 \\
Menunjang Modal BUMDES & 150.000 .000 \\
\hline Pengadaan Gedung PAUD & 1.828 .360 .000 \\
\hline TOTAL & \\
\hline Sumber : RKPDes Desa Kalasey Dua Tahun 2017 &
\end{tabular}

Tabel 5 merupakan uraian rincian rencana kerja pemerintah desa yang kemudian akan dijabarkan melalui Anggaran Pendapatan dan Belanja Desa (ABPDes). Untuk Rincian Anggaran Pendapatan dan Belanja Desa dapat dilihat pada Tabel 6.

\begin{tabular}{lr} 
Tabel 6. $\begin{array}{c}\text { Anggaran Pendapatan dan Belanja Desa (APBDes) } \\
\text { Tahun 2017 }\end{array}$ & Desa Kalasey Dua \\
\hline URAIAN & JUMAH (Rp) \\
\hline Pendapatan & 772.117 .000 \\
Dana Desa & 307.037 .000 \\
Alokasi Dana Desa & 15.300 .000 \\
Bagi Hasil Pajak & 11.187 .650 \\
Bagi Hasil Retribusi & 4.400 .000 \\
Pendapatan Asli Desa & 1.110 .041 .650 \\
\hline Total Pendapatan & 237.537 .000 \\
\hline Belanja & 728.202 .000 \\
Penyelenggaraan Pemerintah Desa & 32.487 .650 \\
Pembangunan Desa & 111.815 .000 \\
Pembinaan Masyarakat & 1.110 .041 .650 \\
Pemberdayaan Masyarakat & 270.155 .000 \\
\hline Total Belanja & 118.881 .000 \\
\hline Rincian Belanja Pembangunan Desa & 144.682 .000 \\
Pengaspalan Jalan Lapis Penetrasi & 42.250 .000 \\
Betonisasi & 25.684 .000 \\
Perkerasan Jalan Lapis Sirtu & 12.350 .000 \\
Galian Tanah/Batu Menggunakan Alat & 2.200 .000 \\
Gorong-gorong & \\
Penerangan Jalan Umum Tenaga Surya & \\
Pemeliharaan PJU Tenaga Surya &
\end{tabular}

Tabel 6 menunjukkan bahwa jumlah pendapatan untuk Dana Desa sebesar Rp. 772.117.000 yang mana untuk alokasi terbesar untuk bidang pembangunan desa. Untuk rincian Rencana Penggunaan Dana (RPD) Dana Desa Tahun 2017 dapat dilihat pada Tabel 7.

Tabel 7. Rencana Penggunaan Dana (RPD) Dana Desa, Desa Kalasey Dua Tahun 2017

\begin{tabular}{|c|c|c|c|}
\hline Uraian Kegiatan & Keterangan & Volume Output & Anggaran (Rp) \\
\hline \multicolumn{4}{|l|}{ Bidang Pembangunan Desa } \\
\hline $\begin{array}{l}\text { Pekerjaan Pengaspalan Jalan } \\
\text { Lapen }\end{array}$ & Jalan Desa & 500 Meter & 265.775 .000 \\
\hline Pekerjaan Betonisasi Jalan & Jalan Desa & 400 Meter & 118.881 .000 \\
\hline Pekerjaan Perkerasan Jalan & Jalan Desa & 400 Meter & 114.682 .000 \\
\hline $\begin{array}{l}\text { Pekerjaan Galian Tanah/Batu } \\
\text { Menggunakan Alat }\end{array}$ & Jalan Desa & $40 \mathrm{Jam}$ & 42.250 .000 \\
\hline Gorong-gorong & & 1 Unit & 25.684 .000 \\
\hline Pekerjaan PJU Tenaga Surya & $\begin{array}{l}\text { Penerangan } \\
\text { Jalan }\end{array}$ & 5 unit & 124.350 .000 \\
\hline $\begin{array}{l}\text { Pekerjaan Pemeliharaan PJU } \\
\text { Tenaga Surya }\end{array}$ & Pemeliharaan & 2 Unit & 2.200 .000 \\
\hline \multicolumn{4}{|c|}{ Bidang Pemberdayaan Masyarakat } \\
\hline $\begin{array}{l}\text { Bimtek Pengurus BUMDES } \\
\text { luar daerah } \\
\text { Pengelolaan PAUD } \\
\text { Pengelolaan Posyandu } \\
\text { Bantuan untuk BUMDes } \\
\text { JUMLAH }\end{array}$ & Bimtek & & $\begin{array}{r}10.000 .000 \\
7.500 .000 \\
8.815 .000 \\
22.000 .000 \\
772.117 .000\end{array}$ \\
\hline
\end{tabular}

Pada tahun 2017 penyaluran dana terdiri dari dua tahap. Untuk tahap yang pertama Rp. 463.270.200 dan untuk tahap yang kedua berjumlah $\mathrm{Rp}$. 308.846.800. Untuk biaya yang dipergunakan untuk bidang pembangunan desa berjumlah Rp. 723.802.000 dan untuk bidang pemberdayaan masyarakat $\mathrm{Rp}$. 48.315.000. Untuk semua jumlah anggaran sudah termasuk dengan pajak PPN dan PPH. Untuk pajak PPN sebesar $10 \%$ sedangkan untuk pajak PPH sendiri terbagi atas 2 yaitu PPH 22 dan PPH 23. PPH 22 untuk belanja barang/material diatas 2 juta rupiah, sedangkan untuk PPH 23 untuk sewa alat berat. Untuk pajak PPH 22 sebesar $1.5 \%$ dan PPH 23 sebesar 10\%. Adapun realisasi penyerapan dana desa Tahun Anggaran 2017 dapat dilihat pada Tabel 8. 


\begin{tabular}{|c|c|c|c|}
\hline Uraian & Anggaran (Rp) & Realisasi (Rp) & $\begin{array}{c}\text { Capaian } \\
\text { Output (\%) }\end{array}$ \\
\hline \multicolumn{4}{|l|}{ Bidang Pembangunan Desa } \\
\hline Pekerjaan Pengaspalan Jala & & & \\
\hline Lapen & 265.775 .000 & 265.775 .000 & 100 \\
\hline Pekerjaan Betonisasi Jalan & 118.881 .000 & 118.881 .000 & 100 \\
\hline Pekerjaan Perkerasan Jalan & 114.682 .000 & 114.682 .000 & 100 \\
\hline \multicolumn{4}{|l|}{ Pekerjaan Galian Tanah/Batu } \\
\hline Menggunakan Alat & 42.250 .000 & 42.250 .000 & 100 \\
\hline Gorong-gorong & 25.684 .000 & 25.684 .000 & 100 \\
\hline Pekerjaan PJU Tenaga Surya & 124.350 .000 & 124.350 .000 & 40 \\
\hline Pekerjaan Pemeliharaan PЛ & & & \\
\hline Tenaga Surya & 2.200 .000 & 2.200 .000 & 0 \\
\hline \multicolumn{4}{|l|}{ Bidang Pemberdayaan Masyarakat } \\
\hline \multicolumn{4}{|l|}{ Bimtek Pengurus BUMDES } \\
\hline luar daerah & 10.000 .000 & 10.000 .000 & 100 \\
\hline Pengelolaan PAUD & 7.500 .000 & 7.500 .000 & 100 \\
\hline Pengelolaan Posyandu & 8.815 .000 & 8.815 .000 & 100 \\
\hline Bantuan BUMDes & 22.000 .000 & 22.000 .000 & 100 \\
\hline JUMLAH & 772.117 .000 & 772.117 .000 & \\
\hline
\end{tabular}

Tabel 8 menunjukkan bahwa hasil Laporan Realisasi Penyerapan Dana Desa pada Tahun 2017 ada dua kegiatan yang outputnya tidak $100 \%$ bahkan $0 \%$ yaitu pekerjaan PJU tenaga surya yang hanya mencapaian output $40 \%$ dan pekerjann pemeliharaan PJU tenaga surya yang outputnya yaitu $0 \%$. Output yang dimaksudkan dalam hal ini merupakan hasil akhir pekerjaan fisik yang dilakukan. Dari keterangan Sekretaris Desa bapak Yerry Lukas, hal ini masih menjadi masalah sampai sekarang ini karena, dari 5 unit PJU Tenaga Surya yang telah dipasang tidak ada satupun yang menyala. Ia menyampaikan bahwa hal ini bukan merupakan kesalahan dari pihak desa tetapi merupakan kesalahan dari perusahaan penyedia PJU Tenaga Surya, karena dari pihak desa sendiri telah membayar lunas biaya dari penyediaan bahkan sampai kepada pemeliharaannya.

\section{Evaluasi}

\section{Badan Permusyawaratan Desa}

Informan merupakan Anggota Badan Permusyawaratan Desa yang mengawal pemerintah dalam menjalankan pemerintahan. Sebagai BPD informan mengatakan bahwa sangat memahami mengenai bantuan dana desa ini, karena informan secara langsung terlibat dalam mengawasi pengelolaan dana desa, mulai dari proses perencanaan sampai dengan evaluasi. Informan mengatakan menjelaskan memang ada beberapa permasalahan yang sempat terjadi dalam pengelolaan dana desa ini, seperti pada tahun 2017 yang lalu sempat memang terjadi kesalahan komunikasi atau perbedaan pendapat dari beberapa masyarakat desa dimana ada beberapa masyarakat yang melaporkan adanya penyalahgunaan pengelolaan keuangan serta penyalahgunaan wewenang dari kepala desa, namun permasalahan itu dapat terselesaikan dengan baik serta segala tuduhan terhadap kepala desa tidak benar adanya. Sebenarnya hal itu dapat dijadikan pelajaran oleh seluruh pemerintah desa untuk lebih lagi mensosialisasikan mengenai dana desa ini, karena jumlah anggaran dana desa yang tidak sedikit, sehingga dikemudian hari tidak terjadi lagi kesalahpahaman yang seperti itu. Dan pemerintah serta seluruh masyarakat dapat bersama-sama saling membahu dalam memajukan desa ini. Dari hasil pengawasan sampai saat ini pemerintah baik dalam mengelola dana desa ini dan telah sesuai dengan semua prinsip yang ada.

\section{Perangkat Desa}

\section{a. Sekretaris Desa}

Informan merupakan sekretaris desa kalasey dua yang membantu hukum tua dalam mengelola dana desa. Dari hasil wawancara informan mengatakan bahwa dia sangat tahu mengenai dana desa, mengingat informan merupakan salah satu orang yang mengelola dana desa. Informan menyampaikan dana desa ialah program dari pemerintah pusat lewat APBN untuk membantu pembangunan infrastruktur maupun pemberdayaan yang ada didesa. Pada tahun 2017 tidak ada permasalahan nanti setelah tahun 2018 terkendala karena regulasi baru, pada tahun 2017 belum ada pengaturan 30\% untuk padat karya. Pada tahun 2017 masih diperbolehkan pekerjaan menggunakan tenaga mesin sedangkan untuk tahun 2018 sudah tidak bisa karena dibatasi oleh padat karya jadi harus betul-betul memberdayakan masyarakat dengan menggunakan tenaga manusia sepenuhnya. Tujuan ini juga agar masyarakat bisa mendapatkan manfaat artinya mereka bisa bekerja dan menerima gaji, hal ini dapat mengurangi tingkat pengganguran yang ada di desa. Setelah adanya bantuan dana desa banyak sekali perubahan dan perkembangan yang ada didesa, apalagi PAD yang ada didesa tidak menentu adanya dana desa ini sangat-sangat membantu bahkan perubahan sangat signifikan, seperti yang sebelumnya jalan dilorong-lorong masih banyak yang rusak sekarang sudah banyak yang diperbaiki dengan betonisasi, pengeloaan dana desa juga sudah memenuhi prinsip pengelolaan seperti halnya transparansi untuk anggaran bahkan kegiatan harus ada papan proyek bahkan ada papan pengumuman untuk rincian anggaran mulai dari penerimaan sampai pada pengelolaan. Sedangkan untuk partisipasi dari masyarakat sangat kurang, karena pemikiran masyarakat saat ini ketika masuk dengan dana desa segala sesuatu yang terjadi itu harus dibayar, informan mengatakan bahwa dari pemerintah desa sulit untuk memberikan pemahaman kepada masyarakat karena pola pikir masyarakat bahwa desa itu banyak dana sehingga jika ada kegiatan bakti sudah kurang partisipasi dari masyarakat, sehingga swadaya masyarakat sendiri sudah tidak ada padahal dalam APBDes salah satu sumber pendapatan desa yaitu dari swadaya masyarakat. Manfaat dari dana desa untuk desa 
salah satunya yaitu pada tingkat ekonomi, salah satunya dengan adanya perbaikan akses jalan mempermudah tranportasi untuk para pengusaha kecil menengah dalam menjemput penyediaan bahan produksi maupun pada saat pengantaran hasil produksi. Dan juga banyak fasilitas-fasilitas yang bermanfaat untuk masyarakat. Untuk sosialisasi tentang dana desa pemerintah sampai saat ini terus mensosialisasikan setiap ada kesempatan baik itu diacara-acara baik acara suka seperti pesta dan juga di acara duka.

b. Perangkat Desa

Informan mengatakan sebagai perangkat desa informan mengetahui mengenai dana desa, karena informan juga ikut mengambil bagian dalam pengelolaan dana desa. Informan mengatakan "sejauh yang saya ketahui permasalahan yang terjadi mengenai pengelolaan dana desa yaitu masih kurangnya partisipasi dari masyarakat desa dalam pengelolaan dana desa, masih ada perbedaan pemahaman sebagian masyarakat desa dengan pemerintah desa mengenai prinsip dalam pengelolaan dana desa ini. Contohnya dalam prinsip keadilan, menurut pemerintah pengelolaan dana desa ini sudah sangat adil namun sebagian masyarakat masih menganggap jika pengelolaan dana desa ini tidak adil. Memang perlu waktu untuk menyamakan pemahaman antara pemerintah dengan masyarakat, namun sampai saat ini pemerintah terus mengupayakan yang terbaik dalam menyejahterakan seluruh masyarakat desa dengan memanfaatkan anggaran dana desa”.

\section{Evaluasi Masyarakat} berikut :

Adapun hasil kuesioner dari masyarakat sebagai

a. Pengetahuan Tentang Dana Desa

Dana Desa adalah dana yang bersumber dari Anggaran Pendapatan dan Belanja Negara yang diperuntukkan bagi Desa yang ditransfer melalui Anggaran Pendapatan dan Belanja Daerah kabupaten/kota dan lingkungan untuk membiayai penyelenggaraan pemerintah, pelaksanaan pembangunan, pimbinaan masyarakat, dan pemberdayaan masyarakat. Setiap tahun Desa akan menerima Dana Desa dari Pemerintah Pusat, yang penyalurannya dilakakukan melalui kabupaten/kota. Dana Desa lebih diprioritaskan pengunaannya pada bidang pembangunan desa dan bidang pemberdayaan masyarakat. Dalam penyalurannya Dana Desa telah memasuki tahun ke-4, seharusnya seluruh masyarakat desa telah mengetahui mengenai program dana desa ini.

\begin{tabular}{lcc}
\multicolumn{3}{c}{ Tabel 9. Tingkat Pengetahuan Masyarakat Tentang Dana Desa } \\
\hline \multicolumn{1}{c}{ Jawaban Responden } & Jumlah Responden & Persentase (\%) \\
\hline Sangat Tahu & 13 & 26 \\
Tahu & 32 & 64 \\
Kurang Tahu & 3 & 6 \\
Tidak Tahu & 2 & 4 \\
\hline Total & $\mathbf{5 0}$ & $\mathbf{1 0 0}$ \\
\hline
\end{tabular}

Sumber : Data Primer, 2018 
c. Dalam pengelolaan dana desa pihak desa yang mengelola telah mendahulukan kebutuhan yang menjadi prioritas.

Dalam pengelolaannya dana desa seharusnya telah direncanakan dalam penggunaannya, dan harus memprioritaskan kepentingan desa yang lebih mendesak, lebih dibutuhkan dan berhubungan langsung dengan kepentingan sebagian besar masyarakat desa.

\begin{tabular}{lcc}
\multicolumn{2}{c}{ Tabel 11. Mendahulukan Kebutuhan Yang Menjadi Prioritas } \\
\hline \multicolumn{1}{c}{ Jawaban Responden } & Jumlah Responden & Persentase (\%) \\
\hline Sangat Setuju & 24 & 48 \\
Setuju & 21 & 42 \\
Kurang Setuju & 5 & 10 \\
Tidak Setuju & 0 & 0 \\
\hline Total & $\mathbf{5 0}$ & $\mathbf{1 0 0}$ \\
\hline Sumber : Data Primer, 2018 & &
\end{tabular}

Sumber : Data Primer, 2018

Dari Tabel 11 dapat dilihat $90 \%$ masyarakat setuju jika pengelolaan dana desa telah mendahulukan kebutuhan yang menjadi prioritas. Namun masih ada juga 10\% masyarakat yang belum setuju jika pengelolaan dana desa telah mendahulukan kebutuhan yang menjadi prioritas. Contoh kasus yang disampaikan responden sehingga menyatakan tidak setuju yaitu mengenai pengadaan PJU tenaga surya yang mengeluarkan anggaran yang banyak. Responden mengatakan jika anggaran yang sebanyak itu dianggarkan kehal lain contohnya jalan, mungkin hal itu lebih bisa bermanfaat bagi masyarakat.

d. Dalam pengelolaan dana desa pihak desa yang mengelola telah mengutamakan kewenangan desa.

Pemerintah desa harus bisa menggunakan kewenangannya untuk meggunakan dana desa sesuai rencana yang telah di programkan pemerintah pusat. Dalam mengelola dana desa harus mengutamakan kewenangan hak asal usul dan kewenangan lokal berskala desa.

Tabel 12. Mengutamakan Kewenangan Desa

\begin{tabular}{lcc}
\hline Jawaban Responden & Jumlah Responden & Persentase (\%) \\
\hline Sangat Setuju & 19 & 38 \\
Setuju & 27 & 54 \\
Kurang Setuju & 4 & 8 \\
Tidak Setuju & 0 & 0 \\
\hline Total & $\mathbf{5 0}$ & $\mathbf{1 0 0}$ \\
\hline Sumber : Data Primer, 2018 & &
\end{tabular}

Dari data yang diperoleh, 92\% masyarakat setuju jika pengelolaan dana desa telah mengutamakan kewenangan desa. Kewenangan desa merupakan wujud kepentingan kolektif di desa, oleh karena itu peran masyarakat desa dalam penyusunan dan penerapan kewenangan desa harus diberi tempat. Tidak benar jika urusan penyusunan dan penerapan kewenangan desa hanya menjadi urusan pemerintah desa. e. Masyarakat telah berpatisipasi dalam pengelolaan dana desa.

Pemerintah desa juga harus mengutamakan prinsip partisipatif, dimana pemerintah desa berdiskusi dengan masyarakat dalam penggunaan dana desa yanglebih tepat. Dan juga pemerintah menerima usulan-usulan masyarakat yang sekiranya memang layak dan dapat memajukan masyarakat desa. Prinsip partisipasi juga memberikan hak kepada warga desa untuk terlibat dalam setiap pengambilan keputusan pada setiap kegiatan yang diselenggarakan oleh pemerintah desa dimana mereka tinggal. Keterlibatan masyarakat dalam rangka pengambilan keputusan tersebut dapat secara langsung dan tidak langsung.

Tabel 13. Partisipasi Masyarakat

\begin{tabular}{lcc}
\hline Jawaban Responden & Jumlah Responden & Persentase (\%) \\
\hline Sangat Setuju & 15 & 30 \\
Setuju & 29 & 58 \\
Kurang Setuju & 2 & 4 \\
Tidak Setuju & 4 & 8 \\
\hline Total & $\mathbf{5 0}$ & $\mathbf{1 0 0}$
\end{tabular}

Sumber : Data Primer, 2018

Tabel 13 bisa dilihat bahwa $88 \%$ masyarakat mengatakan setuju jika masyarakat telah berpatisipasi dalam pengelolaan dana desa. Keterlibatan masyarakat desa ini penting agar penggunaan dan pengelolaan dana desa bisa lebih tepat sasaran dan manfaatnya akan lebih mengena dengan kepentingan dari masyarakat.

f. Dalam pengelolaan dana desa pihak desa yang mengelola telah mengutamakan pengelolaan secara swakelola dan berbasis sumber daya masyarakat.

Prinsip swakelola dimana pemerintah desa bisa menetapkan dana desa untuk memaksimalkan pengelolaan sumber daya alam di Desa. Namun pemerintah desa dituntut untuk kreatif dan inovatif dalam menggunakan dana desa dengan prinsip swakelola. Pemerintah harus mengutamakan pelaksanaan secara mandiri dengan pendayagunaan sumber daya alam desa, mengutamakan tenaga, pikiran dan keterampilan warga desa dan kearifan lokal.

Tabel 14.Swakelola dan Berbasis Sumber Daya Masyarakat

\begin{tabular}{lcc}
\hline \multicolumn{1}{c}{ Jawaban Responden } & Jumlah Responden & Persentase (\%) \\
\hline Sangat Setuju & 14 & 28 \\
Setuju & 30 & 60 \\
Kurang Setuju & 6 & 12 \\
Tidak Setuju & 0 & 0 \\
\hline Total & $\mathbf{5 0}$ & $\mathbf{1 0 0}$
\end{tabular}

Sumber : Data Primer, 2018

Dari hasil kuesioner yang dijalankan $88 \%$ responden yang setuju jika pengelolaan dana desa telah dilakukan secara swakelola. Karena dalam pengelolaannya pihak pengelola melibatkan masyarakat dalam pengelolaan, dalam hal ini masyarakat dipekerjakan dalam proyek pembangunan fisik yang dilaksanakan. 
g. Dalam pengelolaan dana desa pihak desa yang mengelola telah mempertimbangkan tipologi desa.

Dalam pengelolaan dana desa pemerintah perlu mempertimbangkan keadaan dan kenyataan karakteristik geografis, sosiologi, antropogi, ekonomi, dan ekologi desa yang khas, serta perubahan atau perkembangan dan kemajuan desa. Pemerintah desa perlu memahami kondisi lingkungan desa dengan benar agar nanti dapat menggunakan dana desa untuk membangun fasilitas.

Tabel 15. Mempertimbangkan Tipologi Desa

\begin{tabular}{lcc}
\hline Jawaban Responden & Jumlah Responden & Persentase (\%) \\
\hline Sangat Setuju & 10 & 20 \\
Setuju & 36 & 72 \\
Kurang Setuju & 4 & 8 \\
Tidak Setuju & 0 & 0 \\
\hline Total & $\mathbf{5 0}$ & $\mathbf{1 0 0}$ \\
\hline Sumber : Data Primer, 2018 & &
\end{tabular}

Data Tabel 15 menyatakan bahwa $92 \%$ masyarakat setuju jika pihak pengelola telah mempertimbangkan tipologi desa dalam pengelolaan dana desa. Meski masih ada $8 \%$ yang masih beranggapan bahwa pengelolaan dana desa tidak mempertimbangkan tipologi desa. Mereka berpendapat bahwa pemerintah belum sepenuhnya memahami kondisi lingkungan desa dengan benar sehingga penggunaan dana desa masih belum optimal.

h. Pengelolaan dana desa dilakukan secara transparan.

Transparan adalah prinsip yang menjamin akses atau kebebasan bagi setiap orang untuk memperoleh informasi tentang penyelengaraan pemerintah, yakni informasi tentang kebijakan, proses pembuatan dan pelaksanaannya, serta hasil-hasil yang dicapai. Dana desa yang yang dikucurkan Pemerintah Pusat harus diumumkan secara transparan pada public, khususnya warga desa setempat. Hal tersebut untuk menghindari terjadinya penyelewengan dana, kecurigaan publik, dan supaya pembangunan di desa dapat berlangsung secara kondusif.

Tabel 16. Transparans/Terbuka

\begin{tabular}{lcc}
\hline Jawaban Responden & Jumlah Responden & Persentase (\%) \\
\hline Sangat Setuju & 29 & 58 \\
Setuju & 18 & 36 \\
Kurang Setuju & 1 & 2 \\
Tidak Setuju & 2 & 4 \\
\hline Total & $\mathbf{5 0}$ & $\mathbf{1 0 0}$ \\
\hline Sumber : Data Primer, 2018 & &
\end{tabular}

Dari data yang terima $94 \%$ masyarakat yang setuju jika pengelolaan dana desa telah dilakukan secara transparan, hal ini didasarkan karena pemerintah telah memasang papan APB-Des yang telah mencantumkan rincian keseluruhan dana dari rincian penerimaan sampai dengan rincian pengeluaran, sehingga mayarakat dapat mengetahui jumlah dana yang diterima dan jumlah dana yang dikeluarkan. Kerena pengelolaan keuangan desa memang harus transparan agar masyarakat bisa secara langsung memantau kemana dan untuk apa saja dana yang dikucurkan oleh pemerintah.

i. Pengelolaan dana desa dilakukan secara akuntabel

Akuntabilitas pengelolaan dana desa merupakan upaya untuk mewujudkan tata kelola pemerintah yang baik, dimulai dari proses perencanaan, pelaksanaan, penatausahaan, pelaporan dan pertanggungjawaban. Akuntabilitas menjamin bahwa tiap-tiap kegiatan yang dilakukan oleh pemerintah desa dapat dipertanggungjawabkan kepada seluruh lapisan masyarakat.

\begin{tabular}{lcc} 
Tabel 17. Akuntabel & & \\
\hline Jawaban Responden & Jumlah Responden & Persentase (\%) \\
\hline Sangat Setuju & 20 & 40 \\
Setuju & 26 & 52 \\
Kurang Setuju & 4 & 8 \\
Tidak Setuju & 0 & 0 \\
\hline Total & $\mathbf{5 0}$ & $\mathbf{1 0 0}$
\end{tabular}

Dari tabel 17 dapat disimpulkan bahwa 46 responden (92\%) menyatakan bahwa pengelolaan dana desa dilakukan secara akuntabel. Dalam pengelolaanya dana desa seharusnya telah dilakukan secara akuntabel, hal ini menjadi tugas pemerintah desa untuk lebih mensosialisasikan tentang dana desa.

Dari hasil wawancara dengan BPD dan perangkat desa, serta hasil quisioner yang telah dibagikan kepada masyarakat, dapat ditarik kesimpulan dari jawaban yang diberikan, yaitu :

1) Hampir sebagian besar masyarakat telah mengetahui tentang adanya program dana desa, meskipun masih ada sebagian kecil masyarakat yang belum mengetahui tentang adanya program dana desa ini. Dari informasi yang peneliti dapatkan dilapangan, sebagian masyarakat yang belum mengetahui tentang dana desa ini karena kurangnya sosialisasi pemerintah atau pihak pengelola tentang dana desa ini serta fungsi atau tujuan adanya dana desa ini.

2) Memang dalam pengelolaan tidak akan didapatkan bahwa seluruh pemerintah dan masyarakat akan memiliki pemikiran yang sama tentang hal-hal yang terjadi. Dalam prinsip pengelolaan memang akan ada perbedaan-perbedaan pendapat yang terjadi. Hal ini bukan mengatakan bahwa minoritas yang tidak setuju dengan pengelolaan yang telah dilakukan oleh pihak pengelola mereka salah karena telah memberikan pendapat seperti 
itu namun, pada saat penyusunan anggaran masyarakat juga diundang untuk hadir dalam musyawarah yang dilakukan. Sehingga untuk halhal yang telah direncanakan dan dilakukan bukan semata-mata merupakan keputusan pemerintah maupun pihak pengelola, namun itu merupakan keputusan bersama dari hasil musyawarah.

3) Untuk pernyataan yang menyatakan regulasi baru merupakan kendala, ini harus diingat bahwa pemerintah pusat memiliki maksud yang baik dalam menerapkan peraturan ini. Meski memang ada pekerjaan-pekerjaan yang lebih mudah dilakukan jika menggunakan tenaga mesin, namun dengan ditetapkan regulasi baru adanya pengaturan padat karya dapat membantu masyarakat dalam pengurangan penggangguran yang ada di desa. Karena masyarakat dapat dipekerjakan dan bisa menerima gaji dari hasil pekerjaan itu sehingga dapat membiayai kebutuhan hidup sehari-hari.

\section{KESIMPULAN DAN SARAN}

\section{Kesimpulan}

Secara keseluruhan Dana Desa yang diterima di Desa Kalasey Dua telah dikelola secara baik oleh pemerintah atau pihak pengelola, baik secara prosedur pengelolaan serta prinsip pengelolaan, dan masyarakat sudah dapat merasakan manfaatnya. Dana Desa telah bermanfaat bagi pembangunan di desa, baik pembangunan infrastruktur maupun pemberdayaan masyarakat desa.

\section{Saran}

Berdasarkan kesimpulan diatas, pengelolaan dana desa di Desa Kalasey Dua Kecamatan Mandolang Kabupaten Minahasa telah berjalan dengan baik. Saran dari peneliti untuk pengelolaan kedepannya yaitu :

1. Pemerintah atau pihak pengelola perlu lagi untuk mensosialisasikan program dana desa ini, sehingga semua masyarakat desa dapat mengetahui tentang dana desa, baik dari segi manfaat dan tujuannya.

2. Masyarakat diharapkan bisa lebih lagi untuk berpartisipasi dalam pengelolaan dana desa, baik dari segi ide-ide atau masukan-masukan serta tenaga, agar dana desa ini bisa lebih di manfaatkan sebaik mungkin untuk kesejahteraan desa.

\section{DAFTAR PUSTAKA}

Alumudin, A. 2018. Evaluasi Pengelolaan Dana Desa di Desa Puser Kecamatan Tirtayasa Kabupaten Serang Tahun 2016. Universitas Sultan Ageng Tirtayasa. Serang.

Anomin. 2016 (?). Himpunan peraturan mengenai dana desa. Penerbit Direktorat Jendral Pertimbangan Keuangan Kementrian Keuangan Republik Indonesia.

Rosipah. 2014. Evaluasi Alokasi Dana Desa Di Kecamatan Balaraja Kabupaten Tangerang Tahun 2012. Jurnal Fakultas Ilmu Sosial dan Ilmu Politik Universitas Sultan Ageng Tirtayasa. Serang.

Sudijono, A. 2015. Pengantar Statistik Pendidik. Rajawali Press. Jakarta.

Zaki, A. 2017. Evaluasi Pengelolaan Alokasi Dana Desa Di Desa Gunung Kijang Kecamatan Gunung Kijang Kabupaten Bintan Tahun 2015. Universitas Maritim R aja Ali Haji. Tanjungpinang. 